\title{
The Declaration of Interdependence! Feminism, Grounding and Enactivism
}

\author{
Anya Daly ${ }^{1}$
}

Accepted: 7 December 2020 / Published online: 13 January 2021

(C) The Author(s), under exclusive licence to Springer Nature B.V. part of Springer Nature 2021

\begin{abstract}
This paper explores the issue whether feminism needs a metaphysical grounding, and if so, what form that might take to effectively take account of and support the socio-political demands of feminism; addressing these demands I further propose will also contribute to the resolution of other social concerns. Social constructionism is regularly invoked by feminists and other political activists who argue that social injustices are justified and sustained through hidden structures which oppress some while privileging others. Some feminists (Haslanger and Sveinsdóttir, Feminist metaphysics. In E. N. Zalta (Ed.), Stanford encyclopedia of philosophy. Stanford: Stanford University, 2011) argue that the constructs appealed to in social constructivism are real but not metaphysically fundamental because they are contingent. And this is exactly the crux of the problem - is it possible to sustain an engaged feminist sociopolitical critique for which contingency is central (i.e., that things could be otherwise) and at the same time retain some kind of metaphysical grounding. Without metaphysical grounding it has been argued, the feminist project may be rendered nonsubstantive (Sider, Substantivity in feminist metaphysics. Philosophical Studies, 174(2017), 2467-2478, 2017). There has been much debate around this issue and Sider (as an exemplar of the points under contention) nuances the claims expressed in his earlier writings (Sider, Writing the book of the world. Oxford: Clarendon Press, 2011) and later presents a more qualified account (Sider, Substantivity in feminist metaphysics. Philosophical Studies, 174(2017), 2467-2478, 2017). Nonetheless, I propose the critiques and defences offered by the various parties continue to depend on certain erroneous assumptions and frameworks that are challengeable. I argue that fundamentality as presented in many of these current accounts, which are underpinned by the explicit or implicit ontologies of monism and dualism and argued for in purely rationalist terms which conceive of subjects as primarily reason-responding agents, reveal basic irresolvable problems. I propose that addressing these concerns will be possible through an enactivist account which, following phenomenology, advances an ontology of interdependence and reconceives the subject as first and foremost an organism immersed in a meaningful world as opposed to a primarily reason-responding agent. Enactivism is thus, I will argue, able to
\end{abstract}

Extended author information available on the last page of the article 
legitimize feminist socio-political critiques by offering a non-reductive grounding in which not only are contingency and fundamentality reconciled, but in which fundamentality is in fact defined by radical contingency. My paper proceeds in dialogue with feminists generally addressing this 'metaphysical turn' in feminism and specifically with Sally Haslanger and Mari Mikkola.

Keywords Feminism · Ontology · Metaphysics · Grounding · Fundamentality · Phenomenology $\cdot$ Enactivism

\section{Introduction}

This paper explores the issue whether feminism needs a metaphysical grounding, and if so, what form that might take to effectively take account of and support the socio-political demands of feminism; addressing these demands I further propose will also contribute to the resolution of other social concerns. Social constructionism is regularly invoked by feminists and other political activists who argue that social injustices are justified and sustained through hidden structures which oppress some while privileging others. Some feminists (Haslanger and Sveinsdóttir 2011) argue that the constructs appealed to in social constructivism are real but not metaphysically fundamental because they are contingent. And this is exactly the crux of the problem - is it possible to sustain an engaged feminist socio-political critique for which contingency is central (i.e., that things could be otherwise) and at the same time retain some kind of metaphysical grounding. Without metaphysical grounding it has been argued, the feminist project may be rendered nonsubstantive (Sider 2011, 2017). There has been much debate around this issue and Sider (as an exemplar of the points under contention) nuances the claims expressed in his earlier writings (2011) and later presents a more qualified account (2017). Nonetheless, I propose the critiques and defences offered by the various parties continue to depend on certain erroneous assumptions and frameworks that are challengeable. I argue that fundamentality as presented in many of these current accounts, which are underpinned by the explicit or implicit ontologies of monism and dualism and argued for in purely rationalist terms which conceive of subjects as primarily reason-responding agents, reveal basic irresolvable problems. I propose that addressing these concerns will be possible through an enactivist account which, following phenomenology, advances an ontology of interdependence and reconceives the subject as first and foremost an organism immersed in a meaningful world as opposed to a primarily reason-responding agent. Enactivism is thus, I will argue, able to legitimize feminist socio-political critiques by offering a non-reductive grounding in which not only are contingency and fundamentality reconciled, but in which fundamentality is in fact defined by radical contingency. My paper proceeds in dialogue with feminists generally addressing this 'metaphysical turn' in feminism and specifically with Sally Haslanger and Mari Mikkola. 
In order to motivate the overall discussion of this paper, I would first like to present the iconic painting by Eugène Delacroix of bare-breasted Liberty leading the revolutionaries to overthrow the oppressive regime, as this is, I propose, emblematic of the significance and urgency of feminist critique for socio-political change.

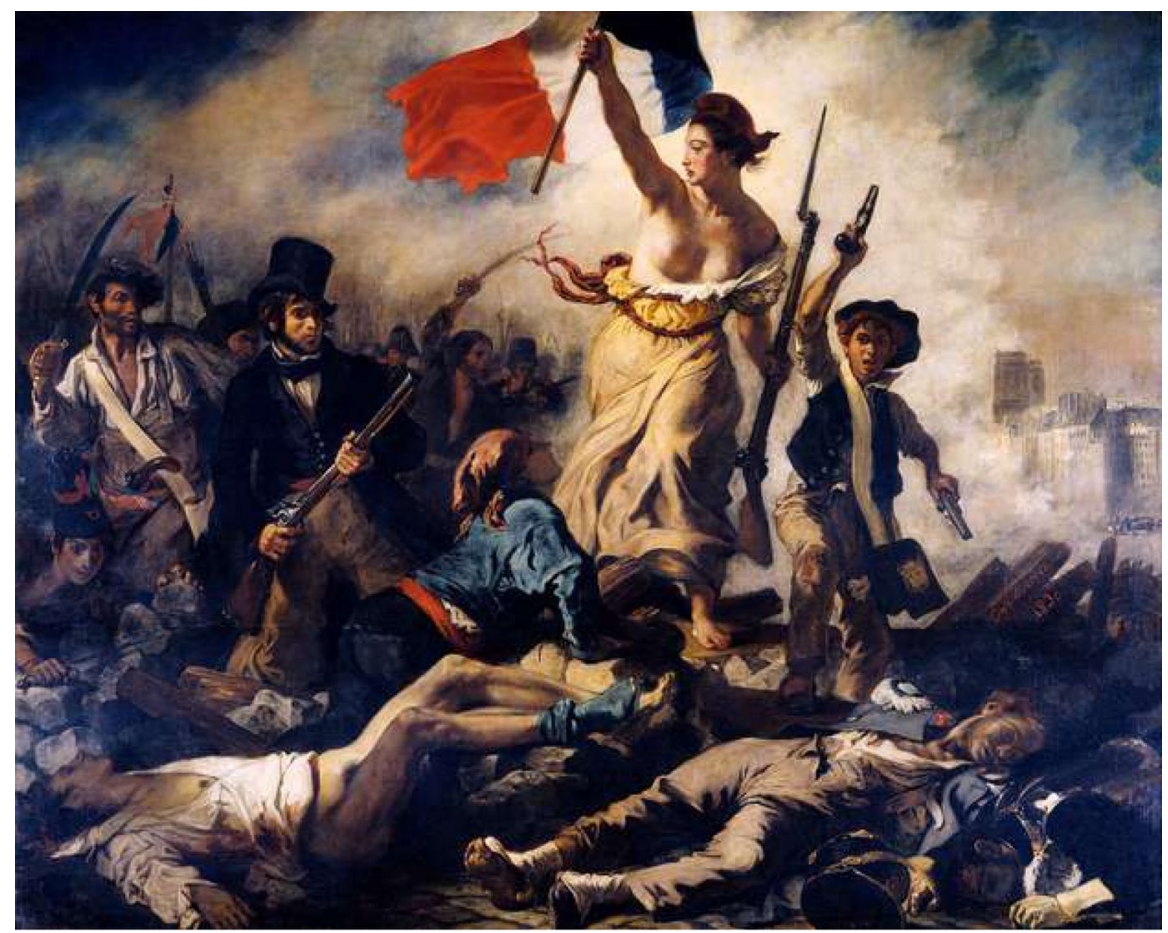

Eugène Delacroix (1830): Liberty Leading the People.

The initial reception of this artwork was very mixed-some rejecting it as an inappropriate image for the Marianne, the mother of France, because as these critics noted she had grimy skin and hairy armpits. For my purposes this image is chosen for a number of obvious reasons but also for one less obvious reason. Liberty, the Marianne, the mother of France, is defiantly leading a throng of revolutionaries from all levels of society, the victims of various injustices; it is thus both a striking and inclusive image. The less obvious reason is my claim that if we can address the gender issues, as represented by the Marianne, then all the other issues, such as poverty, disability, racism and the environment, will also come closer to resolution. Gender is the most basic because it cuts across the other issues of injustice and, moreover, wherever there are instances of, for example, institutional discrimination, disability discrimination, poverty, environmental degradation or racism, it is women who suffer the worst effects of these oppressions (Smith and Hutchison 2004; Ridgeway 2009; Mattsson 2014). Resolving gender issues must therefore be at the forefront of 
change, so that in addressing other injustices the gender aspect must also be given consideration; and further, acting to resolve the gender issue will in itself lead to the amelioration of other social problems. It has been repeatedly demonstrated that addressing gender inequities and empowering women catalyses more widespread and longlasting social and environmental benefits (Addams 1910; Alston and Whittenburg 2013; Gorecki 2014; Mapondera 2016; Godfrey and Torres 2016; Alvarez and Lovera 2016; Perkins 2018; Crease et al. 2018). I give further support to this claim towards the end of the paper. ${ }^{1}$

\section{Terminology and the 'Ontological Difference'}

In writing an earlier paper (Daly 2019), I realized that the 'metaphysical turn' in feminism, which I had noted briefly in that paper, warranted further investigation and so this paper takes up this challenge. The bridging of feminist socio-political concerns and ontological grounding is the key issue, but there is also a complicating challenge in trying to also speak to feminists who work within an analytic framework.

What I have found is that the analytic feminists and the feminists from the phenomenological tradition are sometimes talking past each other and the principal cause seems to be in the use of terms; specifically, ontology and its relation to metaphysics, grounding and fundamentality. So, before I begin examining the concerns of this paper, I would like to clarify some of these terms, though it would seem the definitions even vary between people in the same tradition and there can sometimes also be slippage from ontology to metaphysics within the work of the one scholar.

According to analytic philosophers, 'ontology' is the study of what exists; 'metaphysics' is the study of the basic structure of reality and includes ontology; grounding and fundamentality relate to metaphysics. Quine is often cited as the probable source for these definitions (Chateaubriand 2003). The well-known analytic metaphysician Theodore Sider also endorses such a definition (2017: 8, 9).

The phenomenological view holds that 'ontology' is the study of the underlying, basic structure of reality, the study of Being; metaphysics is the study of reality, what exists, the ontic (as opposed to the ontological); the ontic concerns entities (beings) and these are instantiations of the ontological (Being); grounding and fundamentality concern ontology. And so we have dualist ontologies, monist ontologies, non-dualist ontologies, relational ontologies, physicalism, idealism, etc., In terms of sources for these definitions-we could go back to the pre-Socratics who were concerned to find the underlying ontological substance or mode of Being; for Thaleswater, for Heraclitus-fire, for Democritus-atoms, or to Plato who promoted a

\footnotetext{
1 I am pleased to say that I and many others have long argued the case for this view before ex-President Obama espoused a similar view- "I'm absolutely confident that for two years if every nation on earth was run by women, you would see a significant improvement across the board on just about everything... living standards and outcomes" (December 16th, 2019). https://www.independent.co.uk/news/world/ americas/barack-obama-women-men-singapore-feminism-speech-a9248396.html. For a much earlier presentation of this view see Jane Addams' essay “Women and Public Housekeeping” (1910).
} 
thoroughly dualist account with his Divided Line and the realm of Forms representing ultimate reality; or then to Aristotle who proposed that the universal is not separate from a particular but inherent in it. Indeed, the cornerstone of Aristotle's ontology is his theory that reality is based on the substances of physical objects, not Forms, as he states in the Metaphysics (1028b5). And more recently Heidegger elaborated in a similar manner on the 'ontological difference'-the distinction and relation between the ontological (das Sein) and the ontic (das Seiende) (Haugeland 2013; Wheeler and Heidegger 2018; Slaby 2020a, b). It is this distinction which informs phenomenology more generally and so warrants further discussion.

In his opus, Being and Time, Heidegger begins by declaring: "Our aim in the following treatise is to work out the question of the meaning of Being and to do so concretely" (Heidegger 2001/2008: 19). The ontological difference demarcates between Being (Sein) and entities (Seiendes) and underpins Heidegger's key elaborations of everydayness, three-fold temporality, finitude and authenticity. Ontology is the study of Being but is not itself an entity (Heidegger 2001: 26), it is the ground for the possibility of entities. "Being 'is' always the being of entities but it 'is' never itself one of them" (Haugeland 2013: 53). The difference between the terms is further clarified in Jan Slaby's entries for "Ontology" and "Ontic" in The Cambridge Heidegger Lexicon - "The adjective 'ontological' accordingly refers to what concerns being, ie., what it is for a given entity or class of entities to be-in sharp distinction to the adjective (ontic), which applies to entities as such, i.e., their properties, their various arrangements and behaviors, whatever can be known empirically about them" (Slaby 2020a, b: 551, 542). Heidegger scholar and philosopher John Haugeland makes an illuminating analogy to explain the difference and the relation between ontology and the ontic:

The pertinence of being to entities is something like that of a nation's constitution to its statutes and government. The constitution, in effect, defines what it is for the government to enact a statute and, at the same time, imposes strict conditions on which candidate statutes it could legitimately enact, allowing some as constitutional while ruling out others as unconstitutional. Thus, the constitution both establishes the legislative process by which potential statutes become actual and constrains the allowable results of that process. In so doing, it gives determinate sense to the very notion of legitimate enactment and positive law. (Haugeland 2013: 53)

And while Haugeland concedes the analogy is not perfect in that a "constitution" is an entity, nonetheless, the analogy seems to illuminate the relationship; he suggests that perhaps the difference is better expressed as "constitutionality and enactedness"; and the discovery of entities presuppose disclosure of their Being (Haugeland 2013: 54).

Thus, I am proposing that the discovery of socio-political entities, practices and institutions can be most truly disclosed in relational Being (non-dualist Being) which is the ontology that underwrites both phenomenology and enactivism; the misrecognition of these socio-political entities, practices and institutions through reductive monist (i.e., materialist) or dualist ontologies serves to underwrite oppression and discrimination. 
In tackling this topic, I realize I am wading into deep and contentious waters. This current paper does not pretend to resolve all points of contention, but I hope it can build some bridges and demonstrate the importance of getting both the ontology 'right' and consequently the metaphysics 'right,' thereby contributing to the philosophical surety of feminism. Ontology must be considered in any philosophical (or even scientific) investigation because without being explicitly addressed oppositional and reductive ontologies insinuate themselves into the workings and interpretations of the theoretical framework, inevitably having downstream consequences for practice and action. I am proposing that getting the ontology 'right' will be possible through an enactivist account which is able to legitimize feminist socio-political critiques by offering a non-reductive grounding in which not only are contingency and fundamentality reconciled, but in which fundamentality is in fact defined by radical contingency.

\section{What is All the Fuss About?}

The 'metaphysical turn' in feminist philosophy was arguably galvanized by Ian Hacking's provocative book-The Social Construction of What?-in which he interrogates another divide within philosophy-those philosophers who are avowedly constructionist and those who are entirely dismissive of the idea of construction. This divide extends into the hard sciences, the political sciences, and the human sciences-notably in psychiatry, which is where I have recently found this divide extremely instructive - whether madness is explainable in and reducible to entirely biological-chemical-genetic-neuroscientific terms, or whether, as according to the anti-psychiatrists of the $60 \mathrm{~s}$, madness is the result of social factors and structures; or is the more accurate account somewhere in-between or even elsewhere.

This divide has direct relevance to feminist theory because oppressors have historically invoked the idea of 'natural' categories and metaphysics to justify their oppression (Stone 2007; Witt 2002, 2011). Social constructionists, on the other hand, aim to raise awareness of various social and political injustices, by exposing the hidden structures at work which oppress some while privileging others as a preliminary platform from which to galvanize advocacy and activism. My claim is that it is also crucial to 'go upstream' and discover the underpinning ontologies of which these hidden (ontic) structures are instantiations and to offer an alternative that both does justice to our experience and undercuts oppression in all its guises. As I have argued elsewhere-ontology is political and the political is always ontologically grounded (Daly 2016).

Feminists from both phenomenological and more recently analytic philosophical traditions have stressed that because social structures are often presented as being natural or necessary, feminists are motivated to question the legitimacy of such structures and specifically the social construction of gender. ${ }^{2}$ Analytic

\footnotetext{
2 The ground-breaking insights of Simone de Beauvoir, Maurice Merleau-Ponty, Iris Marion Young and Judith Butler, working within the existential-phenomenological tradition, are the insights that established the feminist philosophical bases for these interrogations (de Beauvoir 2010; Merleau-Ponty 2012; Young 1980; Butler 1990; Daly 2019; McWeeny 2017). Analytic feminist philosophers have subsequently drawn on these
} 
philosopher Sally Haslanger in engaging with Hacking's work, argues that while Hacking's analyses and critiques are appropriate for certain constructionist projects, they do not do justice to the constructionist work in gender and race.

Haslanger is particularly concerned to challenge what she has termed "the debunking project of constructionism"- that if a phenomenon is deemed constructed, it is not in a sense "real" (2012: 5). However, as Haslanger rightly argues, the damaging and pernicious effects of discriminations on this basis are all too real for those who suffer through them. Furthermore, she notes that "topics in metaphysics, epistemology and philosophy of language are not far below the surface of debates over social construction; What is real and what isn't? How do we know what's real? Is there reality beyond what's natural? Is the natural 'fixed,' setting immutable constraints on us? How does language hide or reveal aspects of reality? What illusions does it promote? These are all questions that demand consideration as part of social theory" (Haslanger 2012: 5, 6).

Haslanger's concern with 'debunking' relates to the initial distinction Hacking makes between 'real kinds,' 'natural kinds,' and 'social kinds'. His later distinction between 'indifferent kinds' and 'interactive kinds' nuances his account and intersects interestingly with a phenomenological/ enactivist account. More on that later.

Let's back-track to Hacking so as to establish some conceptual landmarks to these debates.

Hacking's social constructivist schema:

1. X need not have existed, or need not be at all as it is. $\mathrm{X}$, or $\mathrm{X}$ as it is at present, is not determined by the nature of things; it is not inevitable.

They [constructionists] often go further, and urge that:

2. $\mathrm{X}$ is quite bad as it is.

3. We would be much better off if $\mathrm{X}$ were done away with, or at least radically transformed (Hacking 1999: 6).

Hacking also identifies a pre-condition-(0) "In the present state of affairs, X is taken for granted, X appears to be inevitable" (Hacking 1999: 12).

According to Hacking, the $\mathrm{X}$ may refer to many different things such as-ideas, classifications, objects, events, persons, and concepts. In his account he discusses the social construction of 'quarks', the concept of the economy, child abusers, the classifications of the 'mad' and 'women refugees'. All of these he notes exist in "a matrix of social practices, institutions, media, culture and history"-and because they matter to us, they are social and generate social infrastructures that impact on those concerned with real and material consequences. He uses the example of the

\section{Footnote 2 (continued)}

ideas - sometimes with acknowledgement, sometimes not. Regardless, the ideas have taken root as being core to the challenge that feminism presents to mainstream philosophy and socio-political critique. Parallel work has also become established within the philosophy of race (Fanon 2008) and the philosophy of disability (Scully 2014; Mitchell 2020 etc.,) drawing on the same strategies, demonstrating their philosophical cogency and efficacity. 
'woman refugee'; while on the one hand it is possible to argue that this classification according to the formula shows they are constructed, but on the other hand, this revelation of the fact of construction in the identity 'woman refugee,' seems to diminish the significance of how they come to be so classified and thereby become an object of social construction-constructed as a certain kind of human being. The mechanisms of social construction serve the dominant group by imposing a view and socio-political constraints on the subordinated individual or group, who in turn begins to perceive the possibilities in their world according to these social constructed notions of who/ what they are. The internalization of the dominant view reinforces and confirms the 'rightness' of the social construction-so that it appears both real and natural. Part of the feminist project aims to dismantle these constructions and to challenge the inevitability of them (Haslanger 2012: 6). The key aim of the constructionists is to deny the inevitability of the state of affairsthat the classification is not determined by how the world is, it is only a convenient representation serving the dominant group (Hacking 1999: 33).

\section{Hacking's Kinds and Constructionism}

As alerted to previously, Hacking makes an important and useful distinction between objects which are indifferent kinds (objects that lack awareness of how they are classified) and humans who are interactive kinds (humans are aware of how they are classified). Hacking proposes, people classified as such and such may "make tacit or even explicit choices, adapt or adopt ways of living so as to fit or get away from the very classification that may be applied to them .... [he has] called this the looping effect of human kinds" (Hacking 1995) and in his later work he chose to use the more encompassing phrase "interactive kinds" (1999).

What is especially significant is that beyond being aware of how they are classified (purportedly as a particular kind of human being with particular attributes) they can take a meta-cognitive perspective on their situation, the classification and the socio-political forces underpinning the classification and driving the oppression. This is important because taking a meta-cognitive stance allows both the possibility of either entrenching a reductive rationalist totalizing perspective or stepping back from reactivity and appreciating the 'big picture'.

Another element of Hacking conceptual landscape is his schema for the levels of commitment to constructionism. He identifies six levels: Historical (recognition of historical forces); Ironic (we continue on 'as if' the construction is real; we do not invest emotionally or politically in this); Reformist (recognizes the situation is bad and aims to at least modify aspects of it); Unmasking-(undermining by exposing function/ demystifying); Rebellious (includes the previous grades-but remains in the realm of ideas and this is where he locates Haslanger's challenge); and finally, Revolutionary—which combines the rebellious with activism (Hacking 1999: 19).

In my view it is impossible to always demarcate between such 'grades'-because they never exist in isolation and there are deep and powerful interdependent dynamics at work between them all. Moreover, with the last two grades there is the failure to recognize that the realm of ideas is both deeply political and social and so in 
my view Haslanger's project aims to be both rebellious and revolutionary according to his breakdown. She is most certainly concerned with action on the ground not merely working with ideas that have no political impact as Hacking seems to suggest.

What we can extract of particular interest from this breakdown is that across all these grades Hacking claims the phenomenon $\mathrm{X}$ (such as gender or race discrimination) depends on contingent and historical causes - that these could have been otherwise, they are not necessary or inevitable. As he writes:

If contingency is the first sticking point [between the constructionist and the non-constructionist], the second one is more metaphysical. Constructionists tend to maintain that classifications are not determined by how the world is but are convenient ways in which to represent it. They maintain that the world does not come quietly wrapped up in facts. Facts are the consequences of the ways in which we represent the world. The constructionist vision here is splendidly old-fashioned. It is a species of nominalism. It is countered by a strong sense that the world has an inherent structure that we discover. (Hacking 1999: 33)

The claim here is that constructionism is a mere "species of nominalism" which must necessarily oppose the sense of inherent structure of the world.

This is one of the key points of contention for my investigations - that Hacking is setting up an opposition that is challengeable; that there is an opposition between the idea of a world with an inherent structure and constructionism; and so, all constructionists are merely nominalists. In my view, the feminist deployment of constructionism is not a species of nominalism, nor need it in affirming contingency be necessarily opposed to an inherent structure of the world; this will depend on how the inherent structure of the world is conceived. I am proposing that an enactivist account of how the world is inherently structured (as ontologically relational and radically contingent) gives us an entirely new approach to constructionism and hence the dynamics of oppression.

In this way, I wish to defend the claim that the social constructionism feminist philosophers like Haslanger support can be both contingent and metaphysically real, by adopting an enactivist ontology. We can have our metaphysical cake and eat it too!

The corollary argument is that the feminist position nonetheless remains vulnerable to critique if the inherent structure of the world is defined in terms of mainstream ontologies such as, dualism, reductive monism, physicalism, etc. In other words, I am proposing that a feminist position becomes viable within the phenomenological-enactivist framework which advances a non-dualist, relational social ontology (Tzanto and Moran 2015; Magrí and Bortolan 2020). And it is important to note that the 'new materialisms' which are emerging from phenomenology, post-structuralism, and posthumanism offer much that aligns with the view I am advancing and, as some would argue, may even go beyond it. The crucial points of alignment are: that subjectivity is an intersubjectivity; that both identity and difference are engendered in complex interactivity; that human exceptionalism and purely human-centred metaphysics cannot do justice to the complexity of life; that subjects are first and 
foremost organisms immersed in a world and only secondarily reason-responding agents; that the dualist separations of interior and exterior, subject and environment, nature and culture are conceptually and pragmatically unsustainable (Butler 1990; Braidotti 2013, 2019; Fausto-Sterling 2000; Coole and Frost 2010). It is important to acknowledge that these ground-breaking ideas have their provenance in phenomenology and enactivism.

Let's now return to Haslanger and consider in more detail the view that she is advancing.

\section{Sally Haslanger's Response to Hacking}

Haslanger's focus is what she terms 'the debunking project' of social constructionism and its metaphysical implications. As she explains, debunking constructionists aim to achieve two goals: firstly, to 'debunk' the "assumption that a social category is grounded in or justified by nonsocial (natural or metaphysical) facts" or more weakly, that it aims to 'debunk' the "assumption that a thick social category is grounded in and justified by thinly social facts (possibly in conjunction with natural or metaphysical facts)"; secondly, to determine whether within the context, the classification is politically and theoretically useful, or destructive and distorting (Haslanger 2012: 126, 128, 135, 136).

What concerns her in Hacking's account is that he proposes that assertions concerning the social construction of social entities is a redundancy. Why? Because all social entities are constructions anyway (Hacking 1999: 39). In her book Resisting Reality, Haslanger rightly counters that there can be covert constructions generating a blindness to the social and so as she argues, we must demarcate between the socially distinguished, the socially constituted, and the socially caused (2013: 197). With these demarcations in mind we can note that the distinction between 'sex' and 'gender' is the most conspicuous case that needs careful unpacking. De Beauvoir's important assertion that "one is not born but rather becomes woman" (de Beauvoir 2010: 283) highlights that being a woman is more a matter of social structures and forces than one of biological features. Nonetheless, 'sex' and 'gender' are not so easily distinguished as a natural kind in contrast to a social kind-they interact and have varying degrees of mutual determination and entanglement as Butler has incisively proposed (1990: 7); and further, what is clear is that they are not indifferent kinds, they are interactive kinds.

Haslanger addresses these issues through the framework of Hacking's account of 'idea-construction' and 'object-construction'-her evaluations in agreement with Hacking find that gender is both an idea construction and an object construction. Why is this so? The gender classification 'woman' is due to contingent historical and cultural forces and is thus an 'idea construction'. Nonetheless, such an idea construction has real concrete consequences for the person so classified in terms of social position, opportunities and self-understanding. Haslanger counsels that we must ask-does this idea construction support unjust socio-political practices and institutions? Is it clarifying or obscuring? Is it real or merely a fiction used to subordinate women and to serve the status quo? $(2012: 129,133)$. 
Considering object construction in the social context, Haslanger notes that this is not merely a descriptive project tracking pre-existing groups of individuals-but that the classifications both establish and reinforce various groupings and due to the fact that individuals are 'interactive kinds' - they can by both other-attribution and selfattribution come to fit the classification. And here we could reference the groundbreaking article by phenomenologist philosopher-Iris Marion Young_-"Throwing like a girl" (1980)—which detailed the phenomenology and socio-political impact of the construction 'girl,'making visible the inhibitory embodied dimensions of feminine construction that had previously been hidden or obscure.

The unmasking and making visible of the social construction and myth-making at work in oppression is the first step, but more is necessary-as some feminist theorists have argued there is a need to address the metaphysics of the constructed category so that the experience of the oppression and the structures and practices that sustain the experience of oppression are given the status of 'real'. Thus far analytic feminists have been unable to find a suitable candidate. In more recent writings Haslanger does concede that due to "insufficient attention to the social domain," AngloAmerican (analytic) philosophy has been left with "impoverished explanatory and normative theories and few resources to address problems of social injustice that don't have state solutions". She further explains that her 'new' approach will be "materialist, anti-utopian, anti-individualistic, anti-rationalistic-but committed to the possibility of moral knowledge and social justice achieved through contentious politics" (Haslanger 2021). Further to this, I argue that addressing the metaphysics and ontology is crucial to avoid rogue metaphysical commitments being covertly imported into the conceptions and practices of the oppression. We have seen this for centuries now with dualism informing many domains overtly and covertly, thereby ensuring that misapprehensions, erroneous and deleterious oppositions have persisted in the hard sciences, the natural sciences and the human sciences; and now we have reductive materialism doing much the same.

This unresolved problem of metaphysics and ontology is a point of divergence within the community of feminist theorists and activists. Haslanger suggests that part of this divergence can be accounted for by the different questions that are being posed by different theorists; they may as she suggests be answering different questions. But one thing indisputedly unites them; that they are opposed to the oppression of women and the social structures and practices that underwrite such oppression. In her 2017 paper, Haslanger moves again in the direction of phenomenology and enactivism by highlighting the problems of dualism, the problem of the atomistic, individualist subject and noting that a relational account would be a crucial feature of the required ontology - all signature arguments of phenomenology and enactivism. And while she does acknowledge the important work of feminists whose work is informed by European traditions such as phenomenology_de Beauvoir, Irigaray, Young, Butler, etc., and proposes that "our cognitive tools are enacted and embodied in our practices" (Haslanger 2017), she does not take the next necessary step to concede that the solution to her problem of ontology is in fact to be found in the non-dualist, relational ontologies of enactivism and its progenitor-phenomenology.

Haslanger even questions whether 'feminist' (analytic) metaphysics is just mainstream metaphysics but directed at different issues, or she asks-is there a deeper difference? I 
would like now to briefly examine some key points that Mari Mikkola identifies which, in my view, highlight the points of tension among feminist theorists and emphasize the need for an ontology that can effectively take account of the socio-political.

\section{Mikkola's Doing Ontology, Doing Justice}

Mikkola begins her paper, Doing Ontology, Doing Justice: What Feminist Philosophy Can Teach Us About Meta-Metaphysics, by noting that metaphysics has tended to be dismissive of feminist insights, and she aims to rectify this error. She proposes that taking feminist insights seriously will influence ontological theory choice and that feminist philosophy provides helpful methodological tools to "regiment ontological theories" (2015: 782).

For Mikkola contemporary ontology is not a matter so much of conceptual analysis, but rather one of scientific hypothesis-testing about reality's fundamental structure. She distinguishes between the constitutive value of ontology which aims for a "unified, coherent, non-circular, simple, parsimonious total theory" (Mikkola 2015) and the contextual values such as political and moral values, which are embedded in a social context. The mainstream view is that the latter contextual values should not be considered in ontological theory choice-that rather, as previously stated, ontology and metaphysics are a matter of discovery of how the world is, not choice. She, however, suggests that they may in fact be compatible and seeks to investigate this compatibility by a closer analysis of grounding. And at this point I am in complete agreement with Mikkola and applaud the recognition that values cannot be expunged from ontology and metaphysics. And we note some aspects of this plan that are very enactivist in conception, for example, the embeddedness in the social.

Analytic feminist philosophers aim both to critique patriarchal social structures by utilizing mainstream philosophical tools and to shape mainstream philosophy with the help of feminist political insights [specifically those concerning gender justice]. From this perspective, feminist philosophers have advanced influential arguments in ethics, aesthetics, epistemology and political philosophy. (Mikkola 2016: 780, 781)

She notes that the standard 'joint-carving' characterization of metaphysics does not seem able to accommodate the kind of moral and political insights of feminism which are value-laden. And she is correct- 'joint-carving' metaphysics originates in Plato's dualism (Phaedrus) and is not going to take feminism anywhere either in its original formulation or in its more latter-day formulations. ${ }^{3}$

\footnotetext{
3 The problems generated by ontology go back to Plato. The philosopher Alfred North Whitehead declared that all Western philosophy is best characterised as a footnote to Plato (Whitehead 1979: 39). It is the persisting dualism originating from Plato, that underpins some of the most intractable problems in Western philosophy (eg. solipsism and scepticism). "For feminist philosophers this dualism has divided the world and experience into dichotomous categories wherein one term becomes the positive and the other the negative thereby underwriting the denigration of the feminine. And so Merleau-Ponty's work to reinstate the philosophical significance of all that Plato and the heirs to his thought have sought to eliminate or marginalize,- - notably perception, the body, intersubjectivity and also his non-dualist ontology, has immense political implications" (Daly 2019).
} 
Mikkola argues that feminist insights can reveal not only the framing of the ontological theory but also influence which ontological theory is chosen. And this element of choice is something she stresses which goes against the very notion of metaphysics (or ontology); not as something fundamental discovered in our interrogations, but as something optional and capable of being "regimented" by feminist insights, as Mikkola describes.

Mikkola claims she is running a line of argument parallel to that of feminist epistemologists. It proceeds as follows: It is possible to translate feminist epistemologists' insights in the domain of science, which expose the often hidden contextual values at work in scientific paradigms and practices, into the domain of ontological theory choice. A feminist metaphysics, she claims, could potentially be a means of "negotiating with the natural and going beyond notions of fundamentality" (2016: 783). And this is the point of contention; if grounding is a non-causal dependence relation that is asymmetric, irreflexive and transitive, then how can it account for "the relation between fundamental entities and derivative entities, where the derivative (grounded) fact holds in virtue of more fundamental facts (grounds) thereby grounding it" (2016: 785). Importantly, she claims, the relation between the fundamental and the derivative (non-fundamental) cannot itself be fundamental or otherwise an infinite regress would be generated. Mikkola considers two contenders (de Rosset 2013; Bennett 2011), who seek to resolve this impasse, but rejects both. Nonetheless, it is Bennett's account of superinternality as a means of avoiding the infinite regress which finds points of concordance with the phenomenological/ enactivist view. Mikkola notes that Bennett's appeal to 'intrinsic natures' renders her account ineffective for any social ontology. And I agree with this insofar as the notion of 'intrinsic natures' tends to imply fixed natures-however, this needn't be so; in an enactivist account the nature of subjects is to be intrinsically interactive and intersubjective. She finishes by referencing Bennett's view; that this is an irresolvable crazy dilemma "everything is absolutely fundamental or nothing is" (2016: 797). It is this infinite regress which an enactivist account resolves; and the relation which Mikkola rejects erroneously is the key to resolving this puzzle.

Mikkola opts in the end for a skeptical conclusion, that it is not possible to give a unified account of grounding because social ontology does not fit with notions of fundamentality and vice versa; and so one chooses the theory that makes best sense of the social—social ontology and fundamentality are essentially incompatible.

Social ontological cases ill fit the presumption that grounding is fundamental, and the two alternative formulations that reject fundamentality also ill fit explanations of social facts. I subsequently suggested that, relative to the interests driving our inquiries, we must make evaluative decisions about which regimentations(s) of grounding to endorse. We may even have to give up the view that grounding is unified and uniform. We are faced with a theory choice, but what's an ontologist to do? (Mikkola 2016: 802, 803)

From an enactivist perspective this account is not convincing for three reasons: firstly, it concerns entities-either fundamental or derivative-and so still seems to be caught in the notions of ontological substance, one substance that has the intrinsic feature of persistence (the more fundamental) and the other substance the feature 
of contingency, and the relation between these two is implicitly a dualist structure; secondly, she proposes that the fundamentality cannot be in the relation because this would generate a vicious infinite regress - this is challengeable; thirdly, the notion of choosing an ontological theory rather than discovering it and also the notion of regimenting one's ontology seem to lend themselves to arbitrariness and relativism.

The phenomenological/ enactivist account which argues for a non-dualist relational ontology of interdependence offers a non-reductive fundamentality which does not devolve into a vicious infinite regress.

\section{A Phenomenological/Enactivist resolution-'The Declaration of Interdependence'!}

In venturing to give an enactivist response to the above issues in feminism, I think it is extremely important to keep in mind the origins of enactivism; Francisco Varela, who coined the term enactivism, drew on three principle domains to inform his enactivist philosophy-biology, phenomenology and specifically the phenomenology of Merleau-Ponty, and Buddhist Philosophy. The enactivist project he elaborated springs from and has deep concordance with all three domains and I am proposing useful insights to the debates we are considering are to be found in these domains. The pertinent commonalities between these domains of thinking for this particular investigation are these: the importance of lived experience-that subjects are sentient creatures / organisms immersed in meaningful worlds before being reason-responding agents; and the notion of ontological interdependence-that internal relations hold between subjects, and between subjects and worlds.

How does enactivism reconfigure and resolve the tensions between the important socio-political critiques of feminism and the demand for ontological grounding? What is the relationship between constructionism and enactivism? Let's first consider the central insight of enactivism:

[Enactivism] underscores the importance of two interrelated points: that perception consists of perceptually guided action and that cognitive structures emerge from the recurrent sensorimotor patterns that enable action to be perceptually guided... what counts as a relevant world is inseparable from the structure of the perceiver. (Varela 1991, 1992)

The attunement of the organism to the world is reciprocated by the action of the world (the "geographical setting") on us. The world or environment is not something inert, passive, something waiting to be acted upon. The world as correlate of my actions presents itself as somehow receptive, or configured to receive, or afford those actions. (Harney 2007)

Organisms do not passively receive information from their environments, which they then translate into internal representations. Natural cognitive systems ...participate in the generation of meaning by engaging in transformational and not merely informational interactions; they enact a world. (Di Paolo et al. 2014: 39) 
The organism or subject is an active and interactive participant in the construction of his/ her world. While this enactive account finds an important point of concordance with Hacking with regard to interactive kinds, it also goes beyond Hacking's intellectualist/ rationalist account which focuses on the "looping effect" of classification-a knowing that the subject is classified as a certain kind of human being, in acknowledging the bi-directionality of the metaphysical—subject to world and world to subject; in other words, the enactivist account is not so much an epistemological "looping effect" as a metaphysical, constitutive "looping effect". So too enactivism rejects rationalist philosophies, including feminist rationalism, without rejecting rationality tout court; rationality is brought back down to earth in the conception of the subject as first and foremost an organism situated in meaningful interactions with other subjects immersed in a shared world.

In the standard social constructionist account, the interior/ exterior divide is still firmly in place; the oppressed woman and the external social structures and practices which impinge on her sense of self and her capacity to engage freely in her world. With the notion of participatory sense-making, as elaborated by enactivists (Varela et al. 1991; Di Paolo et al. 2014; Gallagher 2005, 2017; Thompson and Cosmelli 2011; and others), there is a dynamic coupling with this environment, a mutual co-determination of the organism/ subject with its enacted world. Nothing is preestablished but must forged and reforged; in phenomenological terms - this is ontological interdependence which supports radical contingency.

... everything in man is contingency in the sense that this human manner of existence is not guaranteed to every human child through some essence acquired at birth, and in the sense that it must be constantly reforged in him through the hazards encountered by the objective body. Man is an historical idea and not a natural species [.....]. Human existence [.....] is the transformation of contingency into necessity by the act of taking in hand. (Merleau-Ponty 2006: 197, 198; 2012: 174)

This is an empowering vision-the fundamental is radically contingent. And so being active participants in the sense-making of their worlds which goes against the status quo, is in itself a political act; being able to maintain an active sense-making role despite and against oppressive structures and coercive forces is how the social domain is transformed. And while we might say-well yes-this is obvious and this is what happens - it is within the enactivist vision that this is ontologically and metaphysically legitimated. As Mikkola notes, citing Bennett (2011), within other accounts—it is just "crazy pants"! (2016: 797); compare also analytic philosopher Elizabeth Barnes' pessimism regarding the impossibility of reconciling fundamentality and feminist metaphysics (2014).

Feminist philosophers have stressed the need to move beyond the view of individuals as fully autonomous, self-determining rational agents towards a view of the individual as embodied, embedded, inherently relational, interdependent, and interactive - and this is exactly what the phenomenological/ enactivist account has already achieved.

Merleau-Ponty's key ideas of chiasm, intertwining and unity-in-difference, achieved in reversible relationality and mutuality reconfigures our understanding of 
sociality; so that the encounter with others, human and non-human, male or female, abled or disabled, white or black calls us to recognise each other as first foremost embodied percipient sentient beings.

... This is also an opening of my body to other bodies: just as I touch my hand touching, I perceive others as perceiving. The articulation of their body on the world is lived by me in the articulation of my body in the world where I see them. .... This is reciprocal: my body is also made up of their corporeality. My corporal schema is a normal means of knowing other bodies and these know my body..... in a universal laterality of the co-perception of the world (Merleau-Ponty 2003: 218).

And so in contrast to other phenomenologists, such as Max Scheler notably, Merleau-Ponty does not in the end even endorse human exceptionalism; our human existence is rooted in our animal, organismic existence, defining our past, present and future. What differentiates humans, nonetheless, is that humans can take a metacognitive stance in virtue of advanced rational capacities detaching them from the direct biological responsiveness of their animal nature; and it is this capacity which may underwrite objectification of humans and non-humans alike, and which renders humans susceptible to jeopardizing biological existence in a way all too familiar with those of us living through the disastrous impacts of climate change.

The feminist sensitivity to power relations, the structures and practices of oppression combined with the enactivist ontology of interdependence provide fertile ground for shifting the old thinking that has been mired in reductionism and oppositions. And this alliance, in my view, will furnish philosophical legitimation and by doing so galvanize solidarity, advocacy and activism.

\section{Conclusion}

Feminist philosophers are currently grappling with the question-is it possible to uphold the value of socio-political critique and at the same time ground these critiques in a metaphysics? As Haslanger has noted, to argue that gender, race, disability etc., is socially constructed seems to suggest that these are in some ways illusory or not real, they are merely socially constructed (Haslanger 2012: 5). However, as stated earlier, the damaging and pernicious effects of discriminations on the basis of race or gender are all too real for those who suffer through them. And so this issue has polarized thinkers-some rejecting ontology and metaphysics out of hand and others are still trying to find a point of reconciliation that does justice to the sociopolitical project of feminism.

The definitions and uses of the terms in the debates are various and disputed but what remains clear is that the issues these debates have identified remain significant. I have argued that the feminist interrogation of gender oppression is of paramount importance for social transformation. It is a no-brainer that addressing gender is one of the most urgent issues facing us today and, as I suggested at the beginning of this paper, maybe it is the one that has the most potential to bring about positive 
change in our world. When we consider the known facts - that educating a girl will bring about significant changes in her community, that childbirths will decrease and so too infant mortality; that women have been outperforming men in education for over a century; that supporting women in microfinance projects will have a synergistic effect and benefit the overall economy of the community; that having women in politics, management, on boards and committees improve their efficiency and outcomes; etc,.

So why is it so difficult to bring about equitable changes? Why is it we have persisting pay gaps, why is it that women with better qualifications and experience are passed over for employment and promotion in favour of young men, why do we have misogynistic media, shocking domestic violence statistics, men in frocks in Rome wondering how to address the appalling revelations of child sexual abuse by clergy, why do we have ugly displays of 'testosterone-rex ${ }^{4}$ leaders promoting ignorance and inciting violence. It's totally mind-boggling!

We are currently in the grip of two major game-changers-the anthropogenic disasters of COVID 19 and climate change and what is increasingly clear is that women as leaders in effectively addressing these issues are conspicuous and male leaders are for the most part equally conspicuous in exacerbating the disasters. And this dynamic has been evident for quite some time:

Time and again, experience has shown that communities fare better during natural disaster when women play a leadership role in early warning systems and reconstruction. Women tend to share information related to community well-being, choose less polluting energy sources, and adapt more easily to environmental changes when their family's survival is at stake. ... Integrating gender perspectives in the design and implementation of policies and laws also helps meet the gender-differentiated impacts of environmental degradation - shortage of water, deforestation, desertification-exacerbated by climate change. (International Labour Organisation 2008: 3)

The collision of such issues and what I propose is the paradigm for the twenty-first century-enactivism, has potential to at least change the thinking as the beginning of change-ontology is political! It is time for a Declaration of Interdependence and for women to be allowed to get on with the job of 'public and global housekeeping'.

Acknowledgements Thanks go to participants for useful feedback for an earlier version of this paper at the conference-E-Approaches to Social Difference and Disparity at the University of Wollongong March 13th \& 14th, 2019. Paper: Feminism, grounding and enactivism—the too-hard basket? Thanks to Maja Hoffmann, Founder and President of the Luma Foundation and to Maria Finders the Curator of Luma Days \#3 2019, Arles, France-“Declaration of Interdependence"-for the opportunity to participate and present my work at this stimulating and beautiful 3 day festival of art and ideas. https://lumad ays.org/en/. Thanks go to participants for useful feedback for an earlier version of this paper at the Australasian Society of Continental Philosophy Annual Conference, University of Melbourne, Australia, 4th-6th December 2019. Paper: A Declaration of Interdependence: Feminism, grounding and enactivism.

\footnotetext{
${ }^{4}$ Cordelia Fine's book Testosterone Rex -Unmaking the Myths of Our Gendered Minds (2017), follows in Beauvoir's footsteps but brings the discussions into current relevance in engaging with neuroscience, by tackling the pervasive and persisting idea that sex is natural and not cultural.
} 


\section{Compliance with Ethical Standards}

Conflict of interest I currently have no funding and there are no conflicts of interest.

\section{References}

Addams, J. (1910). Women and public housekeeping. New York: National Woman Suffrage Pub. Co., Inc. Alston, M., \& Whittenburg, K. (Eds.). (2013). Research, action and policy: Addressing the gendered impacts of climate change. Dordrecht: Springer.

Alvarez, I., \& Lovera, S. (2016). New times for women and gender issues in biodiversity conservation and climate justice. Development, 59, 263-265.

Barnes, E. (2014). Going beyond the fundamental: Feminism in contemporary metaphysics. Proceedings of the Aristotelian Society, 114(3), 335-351.

Bennett, K. (2011). By our bootstraps. Philosophical Perspectives, 25(1), 27-41.

Braidotti, R. (2013). The posthuman. Cambridge: Polity Press.

Braidotti, R. (2019). Posthuman knowledge. Cambridge: Polity Press.

Butler, J. (1990). Gender trouble: Feminism and the subversion of identity. New York: Routledge.

Chateaubriand, O. (2003). Quine and Ontology. Principia, 7(1-2), 41-74. (Published by NEL-Epistemology and Logic Research Group, Federal University of Santa Catarina (UFSC), Brazil).

Coole, D., \& Frost, S. (2010). New materialisms: Ontology, agency and politics. Durham, N.C.: Duke University Press.

Crease, R. P., Parsons, M., \& Fisher, K. T. (2018). "No climate justice without gender justice": Explorations of the intersections between gender and climate injustices in climate adaption actions in the Philippines. In T. Jafry (Ed.), Routledge handbook of climate justice (pp. 359-377). New York : Routledge.

Daly, A. (2016). Merleau-Ponty and the ethics of intersubjectivity. London: Palgrave Macmillan.

Daly, A. (2019). A phenomenological grounding of feminist ethics. Journal of the British Society for Phenomenology, 50(1), 1-18.

De Beauvoir, S. (2010). The second sex (C. Borde, S. M. Chevallier, Trans.). New York: Alfred A. Knopf.

De Rosset, L. (2013). Grounding explanations. Philosophers' Imprint, 13(7), 1-26.

Di Paolo, E., Rhodhe, M., \& de Jaegher, H. (2014). Horizons for the enactive mind: Values, social interaction and play. In J. Stewarts, O. Gappene, \& E. A. Di Paolo (Eds.), Enaction: Toward a new paradigm for cognitive science. Boston: MIT Press.

Fanon, F. (1952).Peau noire, masques blancs, Seuil. Black Skin, White Masks (R. Philcox, Trans.). New York: Grove Books, 2008.

Fausto-Sterling, A. (2000). Sexing the body: Gender politics and the construction of sexuality. New York: Basic Books.

Fine, C. (2017). Testosterone rex-Unmaking the myths of our gendered minds. London: Icon Books.

Gallagher, S. (2005). How the body shapes the mind. Oxford: Oxford University Press.

Gallagher, S. (2017). Enactivist interventions; Rethinking the mind. Oxford: Oxford University Press.

Godfrey, P., \& Torres, D. (Eds.). (2016). Systemic crises of global climate change: Intersections of race, class and gender. New York: Routledge.

Gorecki, J. (2014). 'No climate justice without gender justice': Women at the forefront of the People's Climate March. Feminist Wire. September 2014. Retrieved 2 August 2020 from https://thefeminis twire.com/2014/09/climate-justice-without-gender-justice-women-forefront-peoples-climate-march/.

Hacking, I. (1995). Rewriting the soul: Multiple personality and the sciences of memory. Princeton, NJ: Princeton University Press.

Hacking, I. (1999). The social construction of what? Cambridge, MA: Harvard University Press.

Harney, M. (2007). Merleau-Ponty, ecology, biosemiotics. In S. L. Cataldi \& W. Hamrick (Eds.), Merleau-Ponty and environmental philosophy, dwelling in the landscapes of thought (pp. 133-146). Albany, N.Y.: State University of New York Press.

Haslanger, S. (2012). Resisting reality: Social construction and social critique. Oxford: Oxford University Press. 
Haslanger, S. (2017). The sex/gender distinction and the social construction of reality. In A. Garry, S. J. Khader, \& S. Alison (Eds.), The Routledge companion to feminist philosophy (pp. 157-167). New York: Routledge.

Haslanger, S. (2021). Doing justice to the social. In S. Collins, B. Epstein, S. Haslanger, \& B. Schmid (Eds.), Oxford handbook on social ontology. Oxford: Oxford University Press.

Haslanger, S., \& Sveinsdóttir, Á. (2011). Feminist metaphysics. In E. N. Zalta (Ed.), Stanford encyclopedia of philosophy. Stanford: Stanford University.

Haugeland, J. (2013). In J. Rouse (Ed.), Dasein disclosed: John Haugeland's Heidegger. Cambridge, MA: Harvard University Press.

Heidegger, M. (2001/2008). Being and time (J. Macquarie, E. Robinson, Trans.). New York: Harper and Row.

International Labour Organisation. (2008). Green jobs: Improving the climate for gender equality too. Geneva: International Labour Organisation.

McWeeny, J. (2017). Beauvoir and Merleau-Ponty. In L. Hengehold \& N. Bauer (Eds.), A Companion to Simone de Beauvoir (pp. 211-223). Malden, MA: John Wiley and Sons.

Magrí, E., \& Bortolan, A. (Eds.). (2020). Empathy, intersubjectivity and the social world. Berlin: De Gruyter.

Mapondera, M. H. (2016). Black women reclaim the conversation on racism. Feminist wire. February 17th, 2016. Retrieveed 2 August 2020 from https://thefeministwire.com/2016/02/black-women-andglobal-racism/

Mattsson, T. (2014). Intersectionality as a useful tool: Anti-oppressive social work and critical reflection. Affilia, 29(1), 8-17. https://doi.org/10.1177/0886109913510659.

Merleau-Ponty, M. (2003). Nature: Course notes from the College de France. Notes compiled by Dominique Seglard. (R. Vallier, Trans.). Evanston: Northwestern University Press.

Merleau-Ponty, M. (2006). The phenomenology of perception (C. Smith, Trans.). London: Routledge.

Merleau-Ponty, M. (2012). The phenomenology of perception (D. Landes, Trans.). London: Routledge.

Mikkola, M. (2015). Doing ontology and doing justice: What feminist philosophy can teach us about meta-metaphysics. Inquiry, 58(7-8), 780-805. https://doi.org/10.1080/0020174X.2015.1083469.

Mikkola, M. (2016). Feminist metaphysics. In Oxford bibiographies. Last modified November 30th 2015. https://doi.org/10.1093/obo/9780195396577-0297. https://www.oxfordbibliographies.com/view/ document/obo-9780195396577/obo-9780195396577-0297.xml.

Mitchell, J. (2020). Disability and the inhuman. In A. Daly, D. Moran, F. Cummins, \& J. Jardine (Eds.), Perception and the inhuman gaze: Perspectives from philosophy, phenomenology and the sciences. New York: Routledge.

Perkins, P. E. (2018). Climate justice, gender and intersectionality. In T. Jafry (Ed.), The Routledge handbook of climate justice (pp. 349-358). New York : Routledge.

Ridgeway, C. L. (2009). Framed before we know it: How gender shapes social relations. Gender \& Society, 23(2), 145-160. https://doi.org/10.1177/0891243208330313.

Scully, J. L. (2014). Disability and vulnerability: On bodies, dependence, and power. In C. Mackenzie, W. Rogers, \& S. Dodds (Eds.), Vulnerability: New essays in ethics and feminist philosophy (pp. 204-221). Oxford: Oxford University Press.

Sider, T. (2011). Writing the book of the world. Oxford: Clarendon Press.

Sider, T. (2017). Substantivity in feminist metaphysics. Philosophical Studies, 174(2017), 2467-2478.

Slaby, J. (2020a). Ontic. In Wrathall, M. A. (Ed). The Cambridge Heidegger Lexicon. Forthcoming 29 November 2020 (pp. 542-546).

Slaby, J. (2020b). Ontology. In Wrathall, M. A. (Ed). The Cambridge Heidegger Lexicon. Forthcoming 29 November 2020 (pp. 551-559).

Smith, B. G., \& Hutchison, B. (Eds.). (2004). Gendering disability. New Brunswick: Rutgers University Press.

Stone, A. (2007). An introduction to feminist philosophy. Cambridge, UK: Polity.

Thompson, E., \& Cosmelli, D. (2011). Brain in a vat or body in a world? Brainbound versus enactive views of experience. Philosophical Topics, 39, 163-180.

Tzanto, T., \& Moran, D. (Eds.). (2015). Phenomenology and sociality: Discovering the 'We.' New York: Routledge.

Varela, F. (1992). Ethical know-how: Action, wisdom and compassion. Stanford, CA: Stanford University Press.

Varela, F., Thompson, E., \& Rosch, E. (1991). The embodied mind: Cognitive science and human experience. Cambridge, MA: MIT Press. 
Wheeler, M., \& Heidegger, M. (2018). In E. N. Zalta (Ed.), The Stanford encyclopedia of philosophy (Winter 2018 edition). https://plato.stanford.edu/archives/win2018/entries/heidegger/.

Whitehead, A. N. (1979). Process and reality. New York: Free Press.

Witt, C. (2002). Feminist metaphysics. In C. Witt \& L. Antony (Eds.), a mind of one's own (2nd ed., pp. 302-318). Boulder, CO: Westview.

Witt, C. (2011). The metaphysics of gender. Oxford: Oxford University Press.

Young, I. M. (1980). Throwing like a girl: A phenomenology of feminine body comportment, motility and spaciality. Human Studies, 3(2), 137-156.

Publisher's Note Springer Nature remains neutral with regard to jurisdictional claims in published maps and institutional affiliations.

\section{Affiliations}

\section{Anya Daly ${ }^{1}$}

$\triangle$ Anya Daly

anyadaly008@gmail.com; amdaly@unimelb.edu.au

1 University of Melbourne, Melbourne, Australia 